\title{
A method for multiple sequential analyses of macrophage functions using a small single cell sample
}

\section{F.R.F. Nascimento*, \\ D. Rodríguez*, \\ E. Gomes, E.C. Fernvik and M. Russo}

Departamento de Imunologia, Instituto de Ciências Biomédicas, Universidade de São Paulo, São Paulo, SP, Brasil

\begin{abstract}
Correspondence
M. Russo

Departamento de Imunologia ICB IV, USP

Av. Prof. Lineu Prestes, 1730

05508-900 São Paulo, SP

Brasil

Fax: +55-11-3091-7377

E-mail: momrusso@icb.usp.br

Research supported by FAPESP and CNPq.

*Both authors contributed equally to the work.
\end{abstract}

Received November 13, 2002 Accepted May 23, 2003

\begin{abstract}
Microbial pathogens such as bacillus Calmette-Guérin (BCG) induce the activation of macrophages. Activated macrophages can be characterized by the increased production of reactive oxygen and nitrogen metabolites, generated via NADPH oxidase and inducible nitric oxide synthase, respectively, and by the increased expression of major histocompatibility complex class II molecules (MHC II). Multiple microassays have been developed to measure these parameters. Usually each assay requires $2-5 \times 10^{5}$ cells per well. In some experimental conditions the number of cells is the limiting factor for the phenotypic characterization of macrophages. Here we describe a method whereby this limitation can be circumvented. Using a single 96-well microassay and a very small number of peritoneal cells obtained from $\mathrm{C} 3 \mathrm{H} / \mathrm{HePas}$ mice, containing as little as $\leq 2 \times 10^{5}$ macrophages per well, we determined sequentially the oxidative burst $\left(\mathrm{H}_{2} \mathrm{O}_{2}\right)$, nitric oxide production and MHC II (IA ${ }^{\mathrm{k}}$ ) expression of BCG-activated macrophages. More specifically, with $100 \mu \mathrm{l}$ of cell suspension it was possible to quantify $\mathrm{H}_{2} \mathrm{O}_{2}$ release and nitric oxide production after 1 and $48 \mathrm{~h}$, respectively, and $\mathrm{IA}^{\mathrm{k}}$ expression after $48 \mathrm{~h}$ of cell culture. In addition, this microassay is easy to perform, highly reproducible and more economical.
\end{abstract}

\section{Introduction}

Activated macrophages play an essential role in innate and T cell-mediated immunity. In the process of activation, macrophages undergo profound functional changes that result in enhanced antimicrobial and antitumor activities and an increased capacity to present antigens to $\mathrm{T}$ cells. The microbicidal and tumoricidal activities are associated with the generation of highly toxic molecules de-
Key words

- Macrophages

- Nitric oxide

- Hydrogen peroxide

- MHC II

- Method 
the limiting factor usually is the number of cells available the drawback of these methods is the amount of cells required for measuring these three macrophage functions, i.e., roughly one million cells. However, in some experimental conditions the number of available cells is less than one million. Keeping this in mind, we developed a 96-well microassay in which multiple macrophage functional parameters could be determined sequentially with a small number of cells ( $2 \times 10^{5}$ macrophages per well). The results were compared to those obtained with multiple samples. The parameters analyzed were macrophage hydrogen peroxide $\left(\mathrm{H}_{2} \mathrm{O}_{2}\right)$ release, nitric oxide $(\mathrm{NO})$ production and the expression of MHC class II antigens (IA ${ }^{\mathrm{k}}$ ).

We show that the results obtained with a single macrophage sample ( $2 \times 10^{5}$ cells $)$ are similar to those obtained with multiple samples of the same macrophage population. Moreover, the microassay permits the measurement of more than three macrophage functions with only $2 \times 10^{5}$ cells and it is easy to perform, highly reproducible and economical.

\section{Material and Methods}

Mice

$\mathrm{C} 3 \mathrm{H} / \mathrm{HePas}$ mice were originally obtained as breeding units from Institut Pasteur (Paris, France) and have been maintained for many generations in our own Animal Breeding Unit (Biotério de Camundongos Isogênicos, ICB, USP, São Paulo, SP, Brazil) under standard pathogen-free conditions. Animals were age and sex matched, fed sterilized food and acidified water and treated according to ICBUSP Animal Welfare guidelines.

\section{Bacillus Calmette-Guérin treatment}

$\mathrm{C} 3 \mathrm{H} / \mathrm{HePas}$ mice received two intraperitoneal (ip) injections of $2 \mathrm{mg}$ bacillus CalmetteGuérin (BCG, ONCO oral BCG, 500 mg;
Instituto Butantan, São Paulo, SP, Brazil) on day 0 and day 14. Control animals received two ip injections with phosphate-buffered saline (PBS). The peritoneal cells were harvested four days after the last injection.

\section{Peritoneal cell harvesting}

Mice were killed by $\mathrm{CO}_{2}$ asphyxia and the peritoneal cells were aseptically collected by washing the peritoneal cavity with $5 \mathrm{ml}$ sterile ice-cold PBS devoid of calcium and magnesium ions. Total cell counts were performed using a bright-line hemacytometer (Sigma, St. Louis, MO, USA).

\section{Single analysis of macrophage functions using multiple macrophage samples}

Two million peritoneal cells from individual mice were centrifuged at $160 \mathrm{~g}$ for 10 min at $4^{\circ} \mathrm{C}$ and suspended in $1 \mathrm{ml}$ phenol red solution, or complete RPMI 1640 medium or PBS with 5\% fetal calf serum (FCS) for determination of $\mathrm{H}_{2} \mathrm{O}_{2}$ release, NO production and $\mathrm{IA}^{\mathrm{k}}$ expression as described elsewhere (4-7). In all microassays $100 \mu \mathrm{l}$ of the cell suspensions was plated onto each well of a 96-well flat-bottomed tissue culture plate (Corning, New York, NY, USA).

\section{Hydrogen peroxide assay}

$\mathrm{H}_{2} \mathrm{O}_{2}$ release was measured using the horseradish peroxidase-dependent phenol red oxidation microassay (6). The phenol red solution was freshly prepared and consisted of ice-cold Dulbecco's PBS containing 5.5 $\mathrm{mM}$ dextrose, $0.56 \mathrm{mM}$ phenol red (Sigma) and $8.5 \mathrm{U} / \mathrm{ml}$ horseradish peroxidase type II (Sigma). Peritoneal cells suspended in fresh phenol red solution were incubated for $1 \mathrm{~h}$ at $37^{\circ} \mathrm{C}$ in a humid atmosphere containing $5 \%$ $\mathrm{CO}_{2}-95 \%$ air. The reaction was stopped with $10 \mu \mathrm{l} 1 \mathrm{~N} \mathrm{NaOH}$. Absorbance at $620 \mathrm{~nm}$ was measured with a microplate reader (MR 5000, Dynatech Laboratories Inc., Gainesville, VA, 
USA). Conversion of absorbance to $\mu \mathrm{M} \mathrm{H}_{2} \mathrm{O}_{2}$ was deduced from a standard curve obtained with known concentrations of $\mathrm{H}_{2} \mathrm{O}_{2}$ (5 to 40 $\mu \mathrm{M})$ as described by Pick and Keisari (4).

\section{Nitric oxide assay}

For NO determinations, peritoneal cells were suspended in RPMI 1640 medium supplemented with $10 \mathrm{mM}$ HEPES, $11 \mathrm{mM}$ sodium bicarbonate, $100 \mathrm{U} / \mathrm{ml}$ penicillin, $100 \mu \mathrm{g} / \mathrm{ml}$ streptomycin, $2 \mathrm{mM}$ L-glutamine, $23 \mathrm{mM}$ L-asparagine, $1 \mathrm{mM}$ folic acid, 0.1 $\mathrm{mM}$ pyruvic acid, and 5\% FCS. After plating, the cells were incubated for $48 \mathrm{~h}$ at $37^{\circ} \mathrm{C}$ in a humid atmosphere containing $5 \% \mathrm{CO}_{2-}$ $95 \%$ air. The accumulation of nitrite (a stable end product of NO) in supernatants was determined with the standard Griess reagent (5). Briefly, $50 \mu \mathrm{l}$ of the supernatants was incubated with an equal volume of Griess reagent $(1 \%$ sulfanilamide $/ 0.1 \%$ naphthalene diamine dihydrochloride $/ 2.5 \% \mathrm{H}_{3} \mathrm{PO}_{4}$ ) at room temperature for $10 \mathrm{~min}$ and absorbance at 550 $\mathrm{nm}$ was determined. Conversion of absorbance to $\mu \mathrm{M} \mathrm{NO}$ was deduced from a standard curve using known concentration $(5-60 \mu \mathrm{M})$ of sodium nitrite diluted in RPMI medium.

\section{$I^{k}$ expression}

$\mathrm{IA}^{\mathrm{k}}$ expression by the peritoneal macrophages was determined by cell-ELISA using a mouse $\mathrm{H}-39.487 .7$ (IgG2a) anti-IA ${ }^{\mathrm{k}}$ biotinylated monoclonal antibody as described previously (7-9). Briefly, $100 \mu \mathrm{l}$ of peritoneal cells was suspended in PBS-10\% FCS and incubated for $1 \mathrm{~h}$ at $37^{\circ} \mathrm{C}$ in a humid atmosphere containing $5 \% \mathrm{CO}_{2}-95 \%$ air. The nonadherent cells were removed by gentle washing of the wells with PBS-5\% FCS three times. The remaining adherent cells were fixed with $1 \%$ paraformaldehyde dissolved in PBS for $15 \mathrm{~min}$, washed twice with PBS-0.05\% Tween 20 (PBS-T20), and incubated for 30 min with $1 \mu \mathrm{g} / \mathrm{ml}$ of the anti-IA ${ }^{\mathrm{k}}$ biotinylated monoclonal antibody. The plates were washed five times with PBS-T20 and $25 \mu \mathrm{l}$ of ExtrAvidin peroxidase conjugate (Sigma) diluted 1:10,000 in PBS was added to each well. After incubation for $15 \mathrm{~min}$ at room temperature, the wells were rinsed five times with PBS-T20. Five milligrams orthophenylenediamine (Sigma) was diluted in 10 $\mathrm{ml}$ sodium citrate buffer $(0.1 \mathrm{M}$ sodium citrate plus $0.1 \mathrm{M}$ citric acid, $\mathrm{pH}$ 5.0) containing $5 \mu \mathrm{H}_{2} \mathrm{O}_{2}$ (30\%). Ortho-phenylenediamine was added to each well $(100 \mu \mathrm{l})$ and the plate was incubated at room temperature in the dark for $15 \mathrm{~min}$. The reaction was stopped with $50 \mu \mathrm{l} 4 \mathrm{~N}$ sulfuric acid per well and absorbance at $492 \mathrm{~nm}$ was determined.

\section{Sequential analyses of macrophage functions using a single sample of macrophages}

In a single macrophage sample we sequentially determined $\mathrm{H}_{2} \mathrm{O}_{2}$ release, $\mathrm{NO}$ production and $\mathrm{IA}^{\mathrm{k}}$ expression using the same standardized microassays as described above.

Macrophages were harvested and two million peritoneal cells were suspended in 1 $\mathrm{ml}$ freshly prepared phenol red solution. One hundred microliters of the cell suspension (60-80\% macrophages) was plated onto each well and incubated for $1 \mathrm{~h}$ at $37^{\circ} \mathrm{C}$ in a humid atmosphere containing $5 \% \mathrm{CO}_{2}-95 \%$ air. The plates were centrifuged once at $150 \mathrm{~g}$ for 3 min and the supernatants were collected for $\mathrm{H}_{2} \mathrm{O}_{2}$ determination as described above. Next, the wells were washed three times with PBS and the remaining adherent cells were cultured in complete RPMI 1640 medium (100 $\mu \mathrm{l} /$ well) for $48 \mathrm{~h}$. The supernatants were collected and NO production was quantified as described above. Finally, the plates were washed again with PBS and fixed with $25 \mu \mathrm{l}$ $1 \%$ paraformaldehyde for $15 \mathrm{~min}$. After washing three times with PBS the plates were incubated for $15 \mathrm{~min}$ in the presence of PBS containing $0.045 \% \mathrm{H}_{2} \mathrm{O}_{2}(100 \mu \mathrm{l} /$ well $)$ to quench peroxidase activity. After this step, the cell-ELISA assay for MHC class II expression was performed as described above. 


\section{Statistical analysis}

Statistical significance was determined by ANOVA, with the level of significance set at $\mathrm{P}<0.05$. All analyses were carried out using the Instant Program (Graph PAD Software, Inc., San Diego, CA, USA). All determinations were performed in quadruplicate and the results are reported as means $\pm \mathrm{SEM}$.

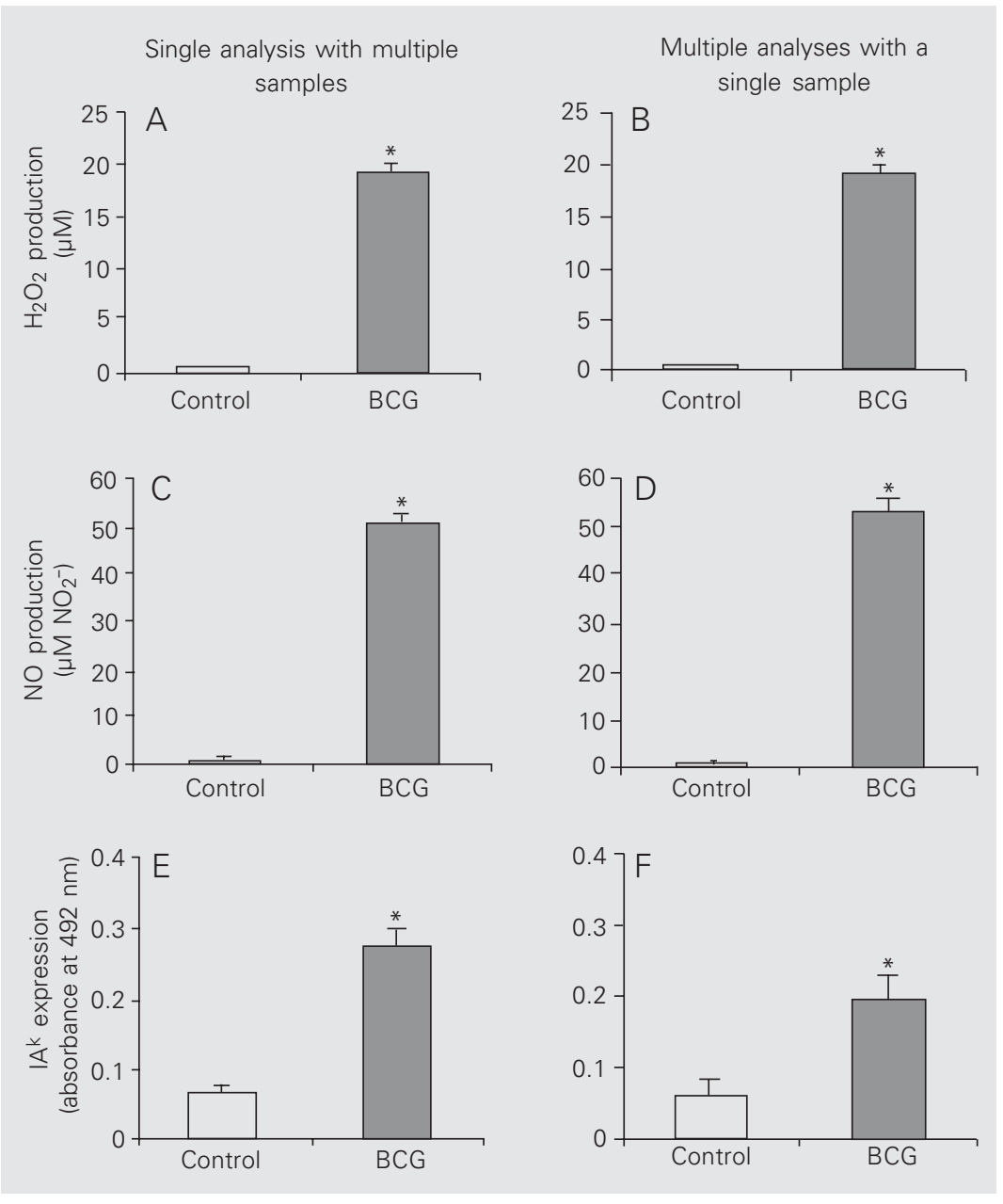

Figure 1. Comparison of $\mathrm{H}_{2} \mathrm{O}_{2}$ release, $\mathrm{NO}$ production and $\mathrm{MHC}$ class II (IAk) expression by bacillus Calmette-Guérin (BCG)-activated peritoneal macrophages. $\mathrm{C} 3 \mathrm{H} / \mathrm{HePas}$ mice were injected ip with $2 \mathrm{mg} \mathrm{BCG}$ or $0.2 \mathrm{ml}$ PBS at days 0 and 14 and the macrophage functions determined 4 days later. $\mathrm{H}_{2} \mathrm{O}_{2}$ release, $\mathrm{NO}$ production and $\mathrm{MHC} \|$ expression were determined using multiple cell samples (left) or a single cell sample (right). $\mathrm{H}_{2} \mathrm{O}_{2}$ release (A and B) was quantified $1 \mathrm{~h}$ after cell culture. NO production ( $\mathrm{C}$ and D) was determined $48 \mathrm{~h}$ after cell culture. IA $\mathrm{A}^{\mathrm{k}}$ expression was evaluated after $1 \mathrm{~h}$ using multiple cell samples (E) or $48 \mathrm{~h}$ after cell culture using a single cell sample (F). One representative experiment of three is shown. Results are reported as means \pm SEM $(N=5)$. ${ }^{*} P<0.05$ for $B C G$ compared to control (ANOVA). There was no statistical difference between single and multiple analyses (ANOVA). MHC, major histocompatibility complex; NO, nitric oxide.

\section{Results and Discussion}

\section{Comparison between the multiple analysis and single analysis methods}

We first determined the macrophage functions by standard methods that use single analysis and multiple samples. We observed that BCG-activated macrophages release and produce large amounts of $\mathrm{H}_{2} \mathrm{O}_{2}$ and $\mathrm{NO}$ and express high levels of $\mathrm{IA}^{\mathrm{k}}$ molecules as compared to nonactivated control macrophages (Figure 1A,C and E). These results demonstrate that our protocol of BCG administration is highly effective in inducing macrophage activation. Next, we determined macrophage functions by the multiple analysis method using a single cell sample. For this procedure we sequentially determined $\mathrm{H}_{2} \mathrm{O}_{2}$ release, $\mathrm{NO}$ production and $\mathrm{IA}^{\mathrm{k}}$ expression. The results obtained were statistically equivalent to those obtained by the standard methods employing single analysis of macrophage functions using multiple cell samples (Figure 1B,D and F). Although not statistically significant, the results of $\mathrm{IA}^{\mathrm{k}}$ expression obtained were always lower for the multiple analysis method compared to the single analysis method. The lower IA ${ }^{\mathrm{k}}$ expression might be due to the time of macrophage culture. Using single analysis, $\mathrm{IA}^{\mathrm{k}}$ expression is measured immediately after cell harvesting, while in multiple analyses it is measured after $48 \mathrm{~h}$. Nevertheless, our results clearly show that when using a single macrophage sample it is possible to determine at least three macrophage functions as accurately as when using standard microassays with multiple macrophage samples. Actually, with the multiple analysis method it is possible to measure more than three functions. For instance, it is possible to analyze macrophage spreading after performing the $\mathrm{H}_{2} \mathrm{O}_{2}$ analysis. For this, the number of spread macrophages can be quantified under an inverted phase contrast microscope as described by Rabinovitch et al. (10). Moreover, it is possible to measure 
different macrophage products such as TNF, GM-CSF, etc., by collecting the supernatants $(50 \mu \mathrm{l})$ from the wells at different time intervals (data not shown).

However, when using the multiple function analysis method, it is fundamental to determine that the measurement of one macrophage function does not interfere with the macrophage response subsequently analyzed. For instance, phorbol myristate acetate (PMA) is often used to trigger the oxidative burst (11). Since PMA activates protein kinase $C$ (12) and this enzyme is known to influence NO production (13), PMA should be avoided or a second macrophage sample without PMA run in parallel should be included. In our experiments we did not include PMA because, as shown previously, freshly explanted BCG-activated macrophages release spontaneously large amounts of $\mathrm{H}_{2} \mathrm{O}_{2}$ (14). In contrast, concanavalin Astimulated macrophages only release significant amounts of $\mathrm{H}_{2} \mathrm{O}_{2}$ when PMA is present (15). Therefore, we suggest that for sequential determination of reactive oxygen and nitrogen intermediate production, at least two macrophage samples (with and without PMA) should be included in the experiment.
Another relevant point regarding $\mathrm{H}_{2} \mathrm{O}_{2}$ determination in the peritoneal cell population is the number of polymorphonuclear cells present in the peritoneal exudates. In the BCG model, at the time of cell harvesting the number of polymorphonuclear cells was minimal and did not interfere with the assay (data not shown). However, if the percentage of polymorphonuclear cells exceeds $5 \%$, an adhesion step for selecting macrophages is required. Thus, peritoneal cells suspended in $\mathrm{Ca}^{2+}$ - and $\mathrm{Mg}^{2+}$-free PBS should be allowed to adhere to a 96 -well plate for $30 \mathrm{~min}$ and, after one PBS washing, the nonadherent cells (including polymorphonuclear cells) are easily removed.

Finally, we wish to emphasize that the major advantage of the multiple function analysis method is that it requires as few as 200,000 cells. Moreover, the method is easy to perform, reproducible and more economical.

\section{Acknowledgments}

We thank Nancy Starobinas, Instituto Butantan, São Paulo, SP, Brazil, for helpful suggestions.

\section{References}

1. Bogdan C, Rollinghoff M \& Diefenbach A (2000). Reactive oxygen and reactive nitrogen intermediates in innate and specific immunity. Current Opinion in Immunology, 12: 64-76.

2. Nathan C \& Shiloh MU (2000). Reactive oxygen and nitrogen intermediates in the relationship between mammalian hosts and microbial pathogens. Proceedings of the National Academy of Sciences, USA, 97: 8841-8848.

3. Long EO (1989). Intracellular traffic and antigen processing. Immunology Today, 10: 232-234.

4. Pick E \& Keisari Y (1980). A simple colorimetric method for the measurement of hydrogen peroxide produced by cells in culture. Journal of Immunological Methods, 38: 161-170.

5. Ding AH, Nathan CF \& Stuehr DJ (1988). Release of reactive nitrogen intermediates and reactive oxygen intermediates from mouse peritoneal macrophages. Comparison of activating cytokines and evidence for independent production. Journal of Immunology, 141: 2407-2412.

6. Pick E \& Mizel D (1981). Rapid microassays for the measurement of superoxide and hydrogen peroxide production by macrophages in culture using an automatic enzyme immunoassay reader. Journal of Immunological Methods, 46: 211-226.

7. Warren MK \& Vogel SN (1985). Bone marrow-derived macrophages: development and regulation of differentiation markers by colonystimulating factor and interferons. Journal of Immunology, 134: 982-989.

8. Pierres M, Kourilsky FM, Rebouah JP, Dosseto M \& Caillol D (1980). Distinct epitopes of Ik gene products identified by monoclonal antibodies. European Journal of Immunology, 10: 950-957.

9. Nascimento FR, Calich VL, Rodriguez D \& Russo M (2002). Dual role for nitric oxide in paracoccidioidomycosis: essential for resistance, but overproduction associated with susceptibility. Journal of Immunology, 168: 4593-4600

10. Rabinovitch M, Manejias RE, Russo M \& Abbey EE (1977). Increased spreading of macrophages from mice treated with interferon inducers. Cell Immunology, 29: 86-95.

11. DeChatelet LR, Shirley PS \& Johnston Jr RB (1976). Effect of phorbol myristate acetate on the oxidative metabolism of human polymorphonuclear leukocytes. Blood, 47: 545-554. 
12. Castagna M, Takai $Y$, Kaibuchi K, Sano K, Kikkawa U \& Nishizuka $Y$ (1982). Direct activation of calcium-activated, phospholipid-dependent protein kinase by tumor-promoting phorbol esters. Journal of Biological Chemistry, 257: 7847-7851.

13. Severn A, Wakelam MJ \& Liew FY (1992). The role of protein kinase $C$ in the induction of nitric oxide synthesis by murine macrophages. Biochemical and Biophysical Research Communications, 188: 9971002.

14. Russo M, Teixeira HC, Marcondes MC \& Barbuto JA (1989). Super- oxide-independent hydrogen peroxide release by activated macrophages. Brazilian Journal of Medical and Biological Research, 22: 1271-1273.

15. Rodriguez D, Cavada BS, Abreu-de-Oliveira JT, de-Azevedo-Moreira $R$ \& Russo M (1992). Differences in macrophage stimulation and leukocyte accumulation in response to intraperitoneal administration of glucose/mannose-binding plant lectins. Brazilian Journal of Medical and Biological Research, 25: 823-826. 